\title{
Menelaah Lalu Lintas Jaringan Internet Relay Chat (IRC) Yang Berbahaya guna Identifikasi Komunikasi Botnet "Plague"
}

\author{
SURYO BRAMASTO \\ Program Studi Informatika \\ Institut Teknologi Indonesia \\ Jalan Raya Puspiptek Serpong, Kota Tangerang Selatan, Banten-15320 \\ Tlp: $+62217561102,+6281563470055$ \\ E-mail: suryo.bramasto@iti.ac.id
}

\begin{abstract}
The research presented in this article aims to identify "plague" botnet communication pattern, with the aid of Wireshark Packet Analyzer as proof of concept (PoC) towards unique communication pattern analysis between infected host and botnet. The research is conducted on public IRC (Internet Relay Chat) network, specifically at the opened domain for botnet research, that is, irc.accesox.net. COMODO Internet Security also used for determining files downloaded by the botnet to identify whether there any malware or not. The observation is done on 60 captured packets, which then the TCP stream excerpt and the protocols hierarchy statistic from those packets being analyzed. Based on the analysis of TCP stream excerpt and the protocols hierarchy statistic, the communication pattern between bot, botmaster, and infected host are known. Wireshark could show the data inside the TCP stream excerpt and all captured protocols. The conducted analysis on TCP stream excerpt and protocols hierarchy statistic is based on RFC 2812 (Internet Relay Chat: Client Protocol - IETF Tools). The analysis on TCP stream excerpt and protocols hierarchy statistic yield botnet activity information for the next step of the analysis of botnet attack, which is dataset and prediction model building. The prediction model can then be implemented to predict whether network traffic is safe or harmful.
\end{abstract}

Keywords: botnet, COMODO internet security, Internet Relay Chat (IRC), RFC 2812, Wireshark

\begin{abstract}
Abstrak. Penelitian yang disajikan pada artikel ini bertujuan mengidentifikasi pola komunikasi botnet "plague" dengan bantuan Wireshark Packet Analyzer untuk menunjukkan proof of concept (PoC) analisis pola komunikasi unik antara host terinfeksi dengan botnet. Penelitian dilakukan terhadap jaringan IRC (Internet Relay Chat) publik, yaitu pada domain yang secara spesifik dibuka guna melakukan penelitian terkait botnet yaitu domain irc.accesox.net. Digunakan juga COMODO Internet Security guna melakukan pemeriksaan terhadap file-file yang diunduh oleh botnet, apakah merupakan file yang berbahaya (malware) atau tidak. Penelitian dilakukan dengan melakukan observasi terhadap 60 paket tertangkap, selanjutnya dilakukan analisis terhadap excerpt dari aliran TCP berikut statistik hirarki protokol pada paket-paket tertangkap. Berdasarkan analisis terhadap pembacaan excerpt dari aliran TCP, serta hirarki protokol tertangkap berikut data di dalamnya maka dapat diketahui pola komunikasi antara bot, bot master, dan infected host. Analisis terhadap hasil pembacaan dilakukan sesuai pemahaman dari RFC 2812 (Internet Relay Chat: Client Protocol - IETF Tools). Wireshark mampu menampilkan komunikasi antara bot, bot master, dan infected host dengan cukup jelas, dan dengan pemahaman terhadap RFC 2812, maka dapat diperoleh informasi aktivitas botnet guna proses kelanjutan dari analisis serangan botnet yakni membangun dataset dan model prediksi, yang mana kemudian model tersebut dapat diimplementasikan guna memprediksi apakah suatu lalu-lintas jaringan aman atau berbahaya.
\end{abstract}

Kata kunci: botnet, COMODO Internet Security, Internet Relay Chat (IRC), RFC 2812, Wireshark 


\section{PENDAHULUAN}

Botnet dalam domain keamanan informasi, digital forensics, dan respon insiden, sering dikaitkan sebagai mekanisme inang dari data ilegal, peluncuran serangan DDOS (Distributed Denial of Services), pencurian informasi, spamming, bitcoin mining, penyebaran ransomware, peluncuran serangan brute force, mengelola akses jarak jauh terhadap perangkat-perangkat terkoneksi, propagasi infeksi ke perangkat lain, dan sebagainya. Jaringan-jaringan Internet Relay Chat (IRC) merupakan media yang populer guna pengendalian jaringan-jaringan bot. Bot-bot berbasis IRC dengan berbagai derajat kerumitan serta dengan struktur perintah yang berbedabeda memiliki kesamaan pada suatu hal. Sebuah bot IRC, saat dieksekusi pada mesin client, maka akan terhubung ke server IRC pada port-port acak dengan nomor-nomor port besar, logs ke dalam kanal yang sudah ditentukan sebelumnya secara pasti, serta kemudian mendengarkan perintah-perintah dari bot master.

Daur hidup botnet dimulai dengan fase infeksi, dimana suatu sistem diserang oleh preconfigured customized malware. Fase koneksi adalah saat sistem terinfeksi melakukan inisiasi hubungan pada IRC TCP service port yang sudah ditentukan guna komunikasi secara remote. Akses bot ke kanal komunikasi dimungkinkan terotentikasi menggunakan username, nickname, password, atau key. Pada fase perintah dan kendali, bot menerima perintah dari bot master melalui kanal komunikasi/channel for communication (C2C) tertentu. Akhirnya pada fase penggandaan, preconfigured customized malware didownload ke dalam bot terinfeksi untuk pengendalian lebih lanjut dan penyebaran infeksi melalui perangkat penyimpan seperti USB flash drive dan semacamnya, atau penyebaran infeksi melalui jaringan komputer terkonfigurasi shared writable.

Menurut Alothman dan Rattadilok (2017), deteksi botnet merupakan salah satu area penelitian aktif selama sepuluh tahun terakhir, dimana para peneliti berusaha keras mengembangkan teknik-teknik yang efektif guna mendeteksi botnet. Mulai dari review terhadap pendekatan-pendekatan yang telah ada terhadap botnet-botnet spesifik, hingga mencoba mengidentifikasi aktivitas botnet dengan melakukan analisis terhadap lalu lintas jaringan. Artikel ini bertujuan untuk menunjukkan sebuah proof of concept (PoC), yang ditujukan guna melakukan analisis terhadap pola komunikasi unik antara host terinfeksi dengan botnet. Analisis digunakan dengan alat bantu Wireshark. Analisis dan observasi akan membantu investigasi awal dari identifikasi lalu lintas pada jaringan tercuplik tentang perilaku bot seperti bagaimana bot masuk ke sebuah kanal, pertukaran pesan antara bot dengan bot master, penyebaran infeksi, dan sebagainya. PoC ini akan merumuskan informasi-informasi guna tahap berikutnya dari analisis serangan botnet yakni proses data analytic guna deteksi botnet.

\section{Landasan Teori}

\section{Botnet}

Menurut Ramneek Puri (2003), botnet adalah sekumpulan program yang saling terhubung melalui internet, yang berkomunikasi dengan program-program sejenis untuk melakukan tugas tertentu. Botnet bisa dipakai untuk menjaga keamanan kanal IRC, mengirimkan spam e-mail, atau berpartisipasi dalam serangan DDoS. Kata botnet berasal dari kata robot dan network.

Botnet dieksploitasi untuk berbagai keperluan, antara lain serangan DoS, penciptaan atau penyalahgunaan relai surat SMTP untuk spam (Spambot), pemalsuan klik, spamdex, pencurian nomor serial aplikasi, identitas masuk log, dan informasi keuangan seperti nomor kartu kredit. Komunitas pengendali botnet sudah lama berjuang memperebutkan gelar pemilik bot terbanyak, konsumsi bandwidth tertinggi, dan mesin terinfeksi paling "berkepentingan tinggi", seperti universitas, perusahaan, dan pemerintahan.

\section{Contoh Operasi Botnet}

Ilustrasi contoh operasi botnet guna pengiriman spam e-mail ditunjukkan pada gambar 1. 


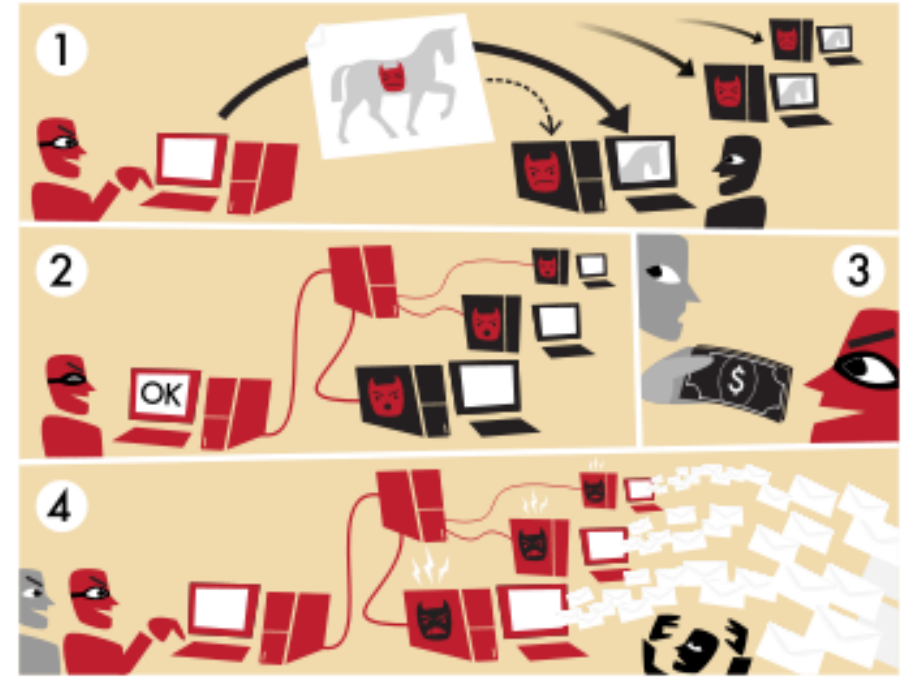

Gambar 1. Operasi Botnet untuk Pengiriman Spam E-mail

Tahapan operasi botnet guna pengiriman spam e-mail adalah sebagai berikut:

1. Operator botnet menyebarkan virus atau worm yang menginfeksi komputer pengguna biasa dengan perantara aplikasi bot.

2. Bot di Personal Computer (PC) yang terinfeksi log ke server $C \& C$ (command \& control) tertentu.

3. Seorang spammer membeli jasa botnet dari operator.

4. Spammer menyampaikan pesan spam kepada operator. Operator menginstruksikan mesin terinfeksi untuk mengirimkan pesan spam melalui panel kendali pada server web.

\section{Ancaman Cyber Berbasis Botnet}

Kasperzyk, Paz, dan Tarapata (2017) menyatakan bahwa dengan melakukan analisis terhadap data historis, dapat diketahui bahwa mayoritas kasus serangan botnet adalah zombies atau bots yang terinfeksi malware. Kemudian berdasarkan penelitian oleh Vitaly Kamluk (2008) yang disitasi oleh Kasperzyk, Paz, dan Tarapata (2017), menyatakan bahwa botnet dapat memberikan pembuatnya derajat tertentu terhadap kendali perangkat yang diserang. Apa yang terjadi pada sejumlah komputer yang terinfeksi botnet tertentu, biasanya berbeda atau bahkan sangat berbeda dibandingkan dengan apa yang terjadi karena jenis bot yang lain. Sejumlah bot mampu melakukan banyak serangan tanpa diketahui oleh pengguna perangkat atau domain yang diserang. Begitupula kemudahan dan biaya pengelolaan botnet yang rendah semakin meningkatkan popularitas botnet. Sfakianakis et al (2018) merilis daftar aktivitas botnet di seluruh dunia, yang ditunjukkan pada tabel 1 . 
Tabel 1. Daftar Aktivitas Botnet pada 2018

\begin{tabular}{|r|l|r|r|}
\hline \multicolumn{2}{|c}{ No. Botnet name } & $\begin{array}{c}\text { No. of IP } \\
\text { addresses }\end{array}$ & Percentage \\
\hline 1 & Conficker & 62221 & $21.19 \%$ \\
\hline 2 & ZeroAccess & 32460 & $11.57 \%$ \\
\hline 3 & Zeus (incl Citadel) & 25311 & $9.03 \%$ \\
\hline 4 & Sality & 14003 & $4.99 \%$ \\
\hline 5 & Zeus GameOver & 12513 & $4.46 \%$ \\
\hline 6 & Ircbot & 10768 & $3.84 \%$ \\
\hline 7 & Bankpatch & 6086 & $2.17 \%$ \\
\hline 8 & Banatrix & 5385 & $1.92 \%$ \\
\hline 9 & Virut & 4014 & $1.43 \%$ \\
\hline 10 & Kelihos & 3922 & $1.40 \%$ \\
\hline & Other & 103750 & $37.00 \%$ \\
\hline
\end{tabular}

Berdasarkan penelitian yang dilakukan Godkin T. (2013) yang disitasi oleh Kasperzyk, Paz, dan Tarapata (2017), botnet juga telah menjadi sumber pemasukan bagi kelompokkelompok cybercriminal besar, seperti misalnya "DNSChanger", yang menggunakan empat juta bot guna menginjeksikan iklan, menghasilkan 14 juta USD selama lima tahun beroperasi. Begitupula "Storm", yang menggunakan 3,5 juta bot guna spamming, menghasilkan sekitar 3,5 juta USD per tahun. Ancaman berikutnya yakni bahwa resiko terhadap serangan berbasis botnet meningkat secara signifikan karena jaringan botnet guna serangan cyber dapat dibeli seperti berikut:

1) Botnet guna serangan DDoS 24 jam: 30 - 70 USD

2) Botnet guna spam email: 10 USD per 1 juta email spam

3) Pembelian 1 paket berisi 2000 bot: 200 USD

4) 1 paket berisi bot-bot yang mampu melakukan serangan DDoS secara efisien: 700 USD

\section{Packet Analyzer}

Packet Analyzer (Packet Sniffer) merupakan perangkat lunak atau perangkat keras yang mampu mencegat (intercept) dan mencatat (log) bagian atau keseluruhan lalu lintas jaringan digital. Proses intercepting dan logging disebut dengan packet capture. Selama aliran data mengalir pada jaringan komputer, Sniffer menangkap setiap paket, dan jika diperlukan melakukan decoding terhadap raw data dari paket sehingga menunjukkan nilai-nilai pada berbagai field dari paket, serta menganalisis isi paket sesuai spesifikasi yang dibutuhkan. Terdapat juga Packet Analyzer untuk jaringan nirkabel (Wireless/WiFi Analyzer).

\section{Kapabilitas Packet Analyzer}

Pada jaringan kabel seperti Ethernet, Token Ring, dan FDDI, dimungkinkan untuk menangkap keseluruhan lalu lintas jaringan dari setiap mesin pada jaringan komputer tersebut (tergantung struktur hub atau switchnya). Pada jaringan modern (kombinasi), lalu lintas dapat ditangkap melalui monitoring port pada network switch atau menggunakan network tap yang lebih handal saat lalu lintas jaringan sibuk. Pada lalu lintas nirkabel, penangkapan dapat dilakukan pada satu demi satu kanal atau beberapa kanal sekaligus menggunakan lebih dari satu adapter.

Pada mode broadcast berbasis kabel, guna menangkap lalu lintas unicast antar mesin, network adapter yang digunakan untuk penangkapan harus dalam mode promiscuous. Sedangkan pada mode broadcast nirkabel, agar dapat dilakukan penangkapan maka network adapter harus berada dalam mode monitor.

Saat lalu lintas ditangkap, keseluruhan isi paket direkam, atau dapat juga hanya pada bagian header saja yang direkam guna mengurangi kebutuhan penyimpanan. Namun jika hanya bagian header saja yang direkam dapat mengakibatkan kurangnya informasi guna keperluan diagnosis permasalahan. 
Setelah informasi tertangkap, maka dilakukan decoding terhadap informasi tersebut dari format raw digital ke format yang terbaca manusia. Packet Analyzer pada umumnya juga memiliki fitur protocol analyzer, yang memungkinkan untuk menampilkan data secara berganda, deteksi error otomatis, menentukan akar terjadinya error, menghasilkan timing diagram, rekonstruksi aliran data TCP dan UDP, berlaku sebagai reference device dengan menghasilkan lalu lintas dan sebagainya.

\section{METODE}

\section{Observasi dan Penyimpulan Pola Komunikasi}

Dilakukan observasi terhadap 60 paket, yang kemudian tersimpan sebagai file .pcap. Dari hasil observasi dilakukan penyimpulan pola komunikasi IRC. Penyimpulan ini mengkelompokkan pola komunikasi normal dan pola komunikasi bot yang berbahaya berdasar ada atau tidaknya malware yang terlibat.

\section{Analisis}

Selanjutnya dilakukan analisis terhadap hasil observasi dan penyimpulan pola komunikasi, yakni yang pertama adalah analisis terhadap properti-properti file .pcap menggunakan Wireshark. Yang kedua adalah analisis terhadap TCP Stream juga menggunakan Wireshark guna memperoleh informasi yang relevan guna lebih memahami komunikasi bot. Yang ketiga yakni analisis hirarki protokol, karena pada umumnya paket-paket mengandung beberapa protokol, dimana juga dilakukan dengan alat bantu Wireshark. Sedangkan proses berikutnya atau yang ketiga adalah analisis terhadap statistik hirarki protokol, yang mana Wireshark mampu menampilkan data dalam semua protokol tercuplik, yang ditampilkan secara hirarkis. Proses analisis dengan alat bantu Wireshark ini mengacu kepada panduan yang dirumuskan oleh Graham Bloice (2019).

\section{Observasi}

Proses observasi dijabarkan sebagai berikut:

1. Secara keseluruhan, terdapat 60 paket yang diobservasi. Identifikasi alamat Internet Protocol (IP) dari paket-paket tersebut yakni:

1) 192.168.45.130: port 1037 (service: ams); port 1038 (service: mtqp)

2) 192.168.45.2: port 53 (service: DNS)

3) 91.121.100.60: Resolved Address- irc.accesox.net; TCP port 5540 (service: sdreport)

2. IP 192.168.45.130: 1037 menginisiasi sebuah query DNS ke 192.168.45.2:53 untuk name resolution dari irc.accesox.net. Respon DNS dari 192.168.45.2 pada 91.121.100.60 dan 91.121.96.162.

3. Paket, 3, 4, dan 5 berisi detail TCP three-way handshake. Handshake tersebut diinisiasi dari 192.168.45.130:1038 dan ditujukan ke irc.accesox.net (91.121.100.60:5540).

4. Paket 6 berisi pesan IRC "PASS" yang digunakan untuk memasang sebuah "password koneksi" oleh host bot 192.168.45.130. "Password koneksi" ini digunakan untuk registrasi koneksi dengan server IRC irc.accesox.net (91.121.100.60).

5. Paket 8 berisi pesan IRC "NICK" yang digunakan untuk menyediakan sebuah username yakni "pLagUe\{" oleh host 192.168.45.130.

6. Paket 10 berisi pesan IRC "USER" yang digunakan untuk menetapkan username oleh host 192.168.45.130. Parameter-parameter asli pada pesan adalah dengan format <username $><$ hostname $><$ servername $><$ realname $>$. Username diidentifikasi sebagai "sKuZ" dan real name sebagai "TeaM UniX b0at 0.4".

7. Paket 12 yakni IRC server-irc.accesox.net (91.121.100.60) membalas ke host 192.168.45.130. Balasan berasal dari server "sex.accesox.net", yang mengindikasikan pesan otorisasi oleh server. 
8. Paket 15 yakni IRC server-irc.accesox.net melakukan ping terhadap client (192.168.45.130) dengan sebuah hostname karena server tidak dapat mengenali hostname. Perintah PING digunakan untuk menguji keberadaan client bot.

9. Paket 16 yakni respon PONG mengindikasikan sebuah balasan oleh client bot ke pesan PING dari server IRC.

10. Paket 18 merupakan komunikasi yang mengindikasikan balasan dari server "sex.accesox.net" yang tercipta pada "mar 252011 at 02:34:51 CET", yang mana server tersebut menjalankan "Unreal3.2.9-rc1" (sebuah server IRC open source). Server IRC menerima client bot dengan rentetan balasan. Seperti yang dinyatakan Christophe Kalt (2000) pada RFC 2812, rentetan balasan mengindikasikan keberhasilan registrasi dari client bot.

11. Paket 19 mengindikasikan bahwa pesan dari client host untuk mengubah visibility mode untuk pengguna tersembunyi pada server IRC.

12. Paket 21 dan 23 merupakan perintah JOIN yang dikeluarkan client bot dan permintaan untuk mulai mendengarkan kanal spesifik yakni "verga".

13. Paket 25 merupakan PRIVMSG yang digunakan oleh client untuk mengirim pesan pribadi ke kanal "verga". Pesan yang dikirimkan adalah dalam bahasa Spanyol yakni "NueVo PuTo InfeCcIoN".

14. Paket 27 berisi detail respon perintah dari server IRC. Mengindikasikan 56 user terlihat dan 189 user tak terlihat pada 9 server. Kemudian juga menginformasikan kepada client host bahwa nickname tidak terdaftar.

15. Paket 30 sampai 43 mengindikasikan registrasi ulang yang diinisiasi client bot

16. Paket 45 mengindikasikan pesan perintah dari bot "pLagUe" untuk mengunduh sebuah file executable yakni "plaga.exe" dari http://www.freewebtown.com/redzone/ ke dalam system drive dari client bot (C:〈jiji).

17. Paket 53 berisi detail respon dari client bot ke server IRC yang menyatakan infeksi virus ke dalam "autorun.inf" dari USB flash drive yang terpasang.

\section{HASIL DAN PEMBAHASAN \\ Ringkasan Komunikasi IRC}

Ringkasan komunikasi IRC untuk paket-paket yang harus diperhatikan ditunjukkan pada gambar 2 dan gambar 3. 
Faktor Exacta 12(2): 145-155, 2019

p-ISSN: 1979-276X

e- ISSN: 2502-339X

DOI : 10.30998/faktorexacta.v12i2.3549

\begin{tabular}{|c|c|c|c|}
\hline $\begin{array}{l}\text { Packet } \\
\text { nos. }\end{array}$ & Source & Destination & IRC command \\
\hline 6 & 192.168 .45 .130 & 91.121 .100 .60 & PASS mierdaq \\
\hline 8 & 192.168 .45 .130 & 91.121 .100 .60 & NICK pLagUe\{USA\}64007 \\
\hline 10 & 192.168 .45 .130 & 91.121 .100 .60 & USER SkuZ * ok .4.TeaM UniX bOat 0.4 \\
\hline 12 & 91.121 .100 .60 & 192.168 .45 .130 & $\begin{array}{l}\text { :sex.accesox.net NOTICE AUTH :*** Looking up your } \\
\text { hostname... } \\
\text { :sex.accesox.net NOTICE AUTH :*** Checking ident... } \\
\text { :sex.accesox.net NOTICE AUTH :*** No ident response; } \\
\text { username prefixed with }\end{array}$ \\
\hline 15 & 91.121 .100 .60 & 192.168 .45 .130 & $\begin{array}{l}\text { sex.accesox.net NOTICE AUTH :*** Couldn't resolve your } \\
\text { hostname; using your IP address instead } \\
\text { PING :56EF9DAC }\end{array}$ \\
\hline 16 & 192.168 .45 .130 & 91.121 .100 .60 & PONG 56EF9DAC \\
\hline 18 & 91.121 .100 .60 & 192.168 .45 .130 & $\begin{array}{l}\text { sex.accesox.net } 001 \text { pLagUe }\{\text { USA }\} 64007 \text { :Welcome to the } \\
\text { AccesoX IRC Network } \\
\text { pLagUe\{USA\}64007! SkuZ@59.163.104.34 }\end{array}$ \\
\hline & & & 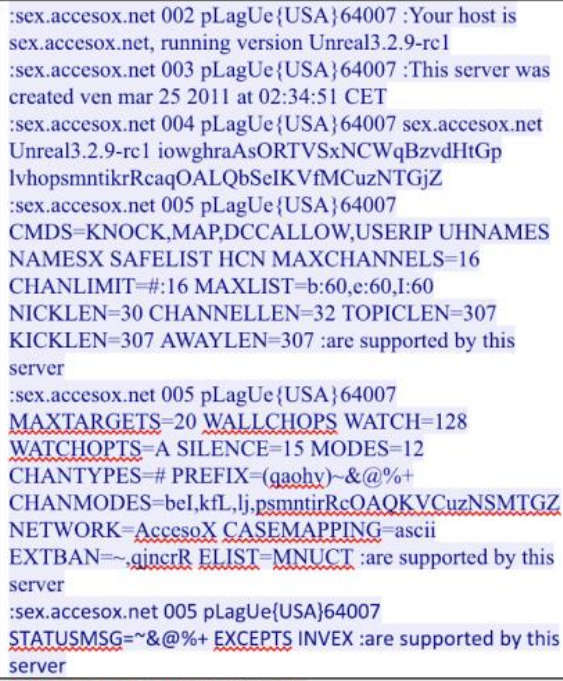 \\
\hline 19 & 192.168 .45 .130 & 91.121 .100 .60 & MODE pLagUe $\{$ USA $\} 64007$-ix \\
\hline 21 & 192.168 .45 .130 & 91.121 .100 .60 & JOIN \#\#verga\#\# \\
\hline 23 & 192.168 .45 .130 & 91.121 .100 .60 & JOIN \#\#verga\#\# \\
\hline 25 & 192.168 .45 .130 & 91.121 .100 .60 & PRIVMSG \#\#verga\#\# :.4.NueVo PuTo InfeCcIoN. \\
\hline
\end{tabular}

Gambar 2. Ringkasan Komunikasi IRC untuk Paket Hingga Nomor 25 


\begin{tabular}{|c|c|c|c|}
\hline 27 & 91.121 .100 .60 & 192.168 .45 .130 & 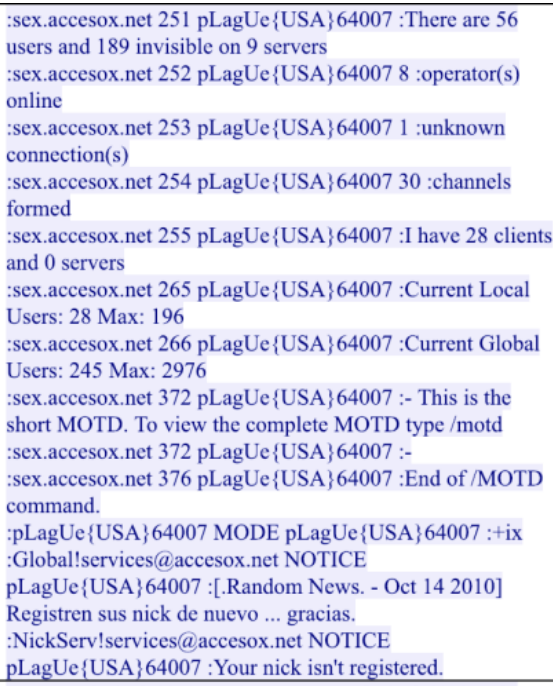 \\
\hline 30 & 91.121 .100 .60 & 192.168 .45 .130 & :pLagUe $\{$ USA $\} 64007$ MODE pLagUe $\{$ USA $\} 64007$ :-ix \\
\hline 33 & 192.168.45.130 & 91.121 .100 .60 & MODE pLagUe $\{$ USA $\} 64007$-ix \\
\hline 35 & 192.168 .45 .130 & 91.121 .100 .60 & JOIN \#\#verga\#\# \\
\hline 37 & 192.168 .45 .130 & 91.121 .100 .60 & JOIN \#\#verga\#\# \\
\hline 39 & 192.168 .45 .130 & 91.121 .100 .60 & MODE pLagUe $\{$ USA $\} 64007$-ix \\
\hline 41 & 192.168 .45 .130 & 91.121 .100 .60 & JOIN \#\#verga\#\# \\
\hline 43 & 192.168 .45 .130 & 91.121 .100 .60 & JOIN \#\#verga\#\# \\
\hline 45 & 91.121 .100 .60 & 192.168 .45 .130 & 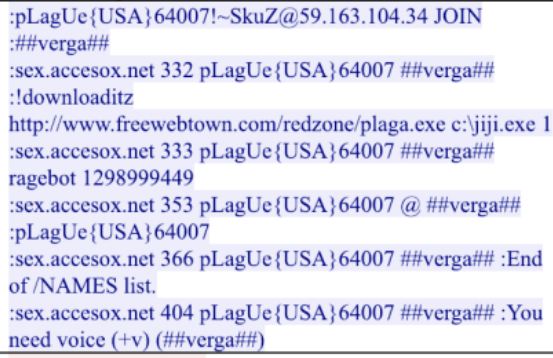 \\
\hline 48 & 192.168 .45 .130 & 91.121 .100 .60 & MODE \#\#verga\#\#-ix \\
\hline 50 & 91.121.100.60 & 192.168 .45 .130 & $\begin{array}{l}\text { :sex.accesox.net } 482 \text { pLagUe }\{\text { USA }\} 64007 \text { \#\#verga\#\# } \\
\text { :You're not channel operator }\end{array}$ \\
\hline 53 & 192.168 .45 .130 & 91.121 .100 .60 & $\begin{array}{l}\text { PRIVMSG \#\#verga\#\# :.4.\{. USB. } 4\} \ldots \text { Injected Virus into } \\
\text {.4.autorun.inf.. on drive.4. D: } \\
\end{array}$ \\
\hline 55 & 91.121 .100 .60 & 192.168 .45 .130 & $\begin{array}{l}\text { sex.accesox.net } 404 \text { pLagUe }\{\text { USA }\} 64007 \text { \#\#verga\#\# :You } \\
\text { need voice }(+v)(\# \# \text { verga\#\#) }\end{array}$ \\
\hline 58 & 91.121 .100 .60 & 192.168 .45 .130 & PING :sex.accesox.net \\
\hline 59 & 192.168 .45 .130 & 91.121 .100 .60 & PONG sex.accesox.net \\
\hline
\end{tabular}

Gambar 3. Ringkasan Komunikasi IRC untuk Paket Nomor 27

Interpretasi dari perintah-perintah IRC yang ditunjukkan pada gambar 2 dan 3 adalah seperti yang dinyatakan Christophe Kalt (2000) pada RFC 2812. Host pada 192.168.45.130 bergabung dengan irc.accesox.net (91.121.100.60) dengan username "sKuZ", kemudian masuk pada kanal "verga". Bot plague\{USA\}64007 menginstruksikan client bot (192.168.45.130) untuk mengunduh sebuah executable file "plaga.exe" dari http://www.freewebtown.com/redzone/, kemudian menyimpan file tersebut dalam system drive C:ljiji, dan menginjeksikan file tersebut ke dalam "autorun.inf" dari perangkat penyimpan yang terhubung melalui port USB (flash drive). Hal ini menunjukkan mekanisme propagasi malware dengan perantara botnet. File plaga.exe sendiri terdeteksi sebagai malware oleh COMODO Internet Security.

Berdasar observasi tersebut dapat disimpulkan bahwa host pada 192.168.45.130 melakukan sebuah query DNS ke 192.168.45.2 untuk resolusi dari irc.accesox.net. Dapat diasumsikan juga bahwa host pada 192.168.45.130 terinfeksi IRC Trojan yang melakukan inisiasi koneksi TCP ke irc.accesox.net, logged ke kancal IRC yang telah ditentukan, serta menyebarkan infeksi pada perangkat penyimpan yang terkoneksi melalui port USB, berdasar perintah dari bot master. 


\section{Analisis Sebuah Excerpt Aliran TCP}

Sebuah excerpt dari aliran TCP ditunjukkan secara detail pada gambar 4, yang mengindikasikan 19 paket client dan 13 paket server.

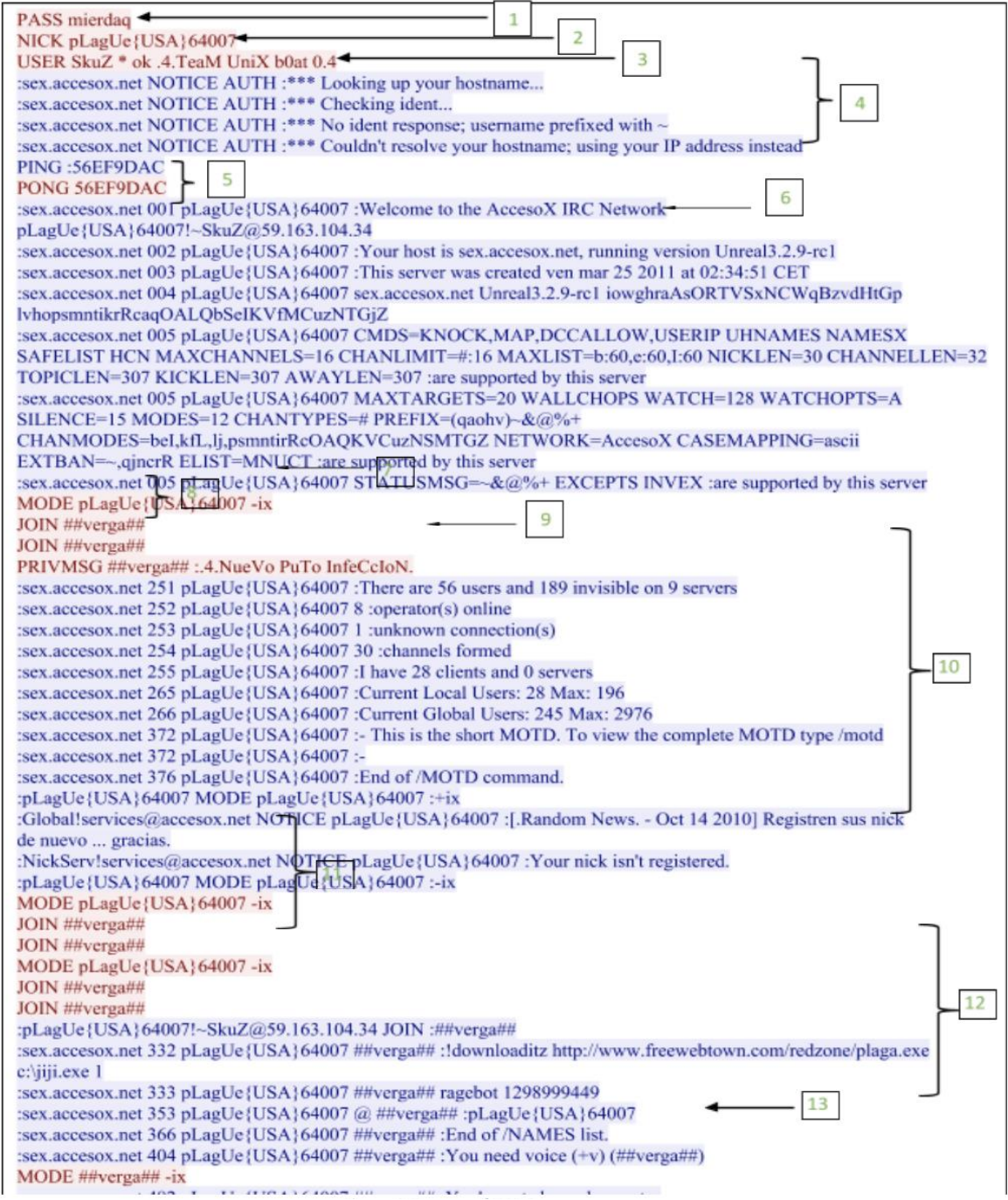

Gambar 4. Excerpt dari Aliran TCP

Keterangan:

1. Password koneksi yang ditentukan oleh host bot

2. Nickname yang ditentukan oleh host bot

3. Username yang ditentukan oleh host bot

4. Notifikasi oleh server IRC sex.accesox.net

5. Perintah PING dari server IRC dan balasan PONG dari bot

6. Informasi jaringan IRC

7. Visibility mode disembunyikan (ditentukan sebagai hidden) oleh bot

8. Client bot meminta pesan dalam rangka mulai memantau kanal spesifik yakni "verga"

9. Pesan pribadi dari client bot pada kanal "verga"

10. Pesan dari botnet pLagUe untuk mengunduh plaga.exe dari http://www.freewebtown.com/redzone/

11. Pesan pribadi dari client bot yang mengindikasikan keberhasilan injeksi dari plaga.exe kedalam autorun.inf dari empat buah perangkat yang tersambung melalui port USB 
Pembacaan dari excerpt dari aliran TCP yang ditunjukkan pada gambar 4, pada dasarnya telah menunjukkan bahwa terjadi siklus botnet. Selanjutnya dilakukan analisis statistik terhadap hirarki protokol. Statistik hirarki protokol ditunjukkan pada gambar 5. Wireshark dapat menampilkan hirarki semua protokol yang dibaca sebagai pemeriksaan awal terhadap kegunaan masing-masing protokol pada jaringan yang dianalisis.

\begin{tabular}{|c|c|c|c|c|c|c|c|c|}
\hline 90 & & eshark $\cdot P_{n}$ & Hierarchy Sta: & Analyz & & & & \\
\hline Protocol & Percent Packets & Packets & Percent B,es & Byes & Bits/s & End Packets & End Bpes & End Bits/s \\
\hline \multirow{4}{*}{$\begin{array}{l}\text { 7. Frame } \\
\text { V Ethernet } \\
\text { Internet Protocol Version } 4 \\
\text { T Transmission Control Protocol }\end{array}$} & 100.0 & 58 & 100.0 & 8447 & 655 & 0 & 0 & 0 \\
\hline & 100.0 & 58 & 9.6 & 812 & 62 & 0 & 0 & 0 \\
\hline & 100.0 & 58 & 13.7 & 1160 & 89 & 0 & 0 & 0 \\
\hline & 100.0 & 58 & 76.7 & 6475 & 502 & 32 & 2482 & 192 \\
\hline Data & 44.8 & 26 & 41.1 & 3473 & 269 & 26 & 3473 & 269 \\
\hline
\end{tabular}

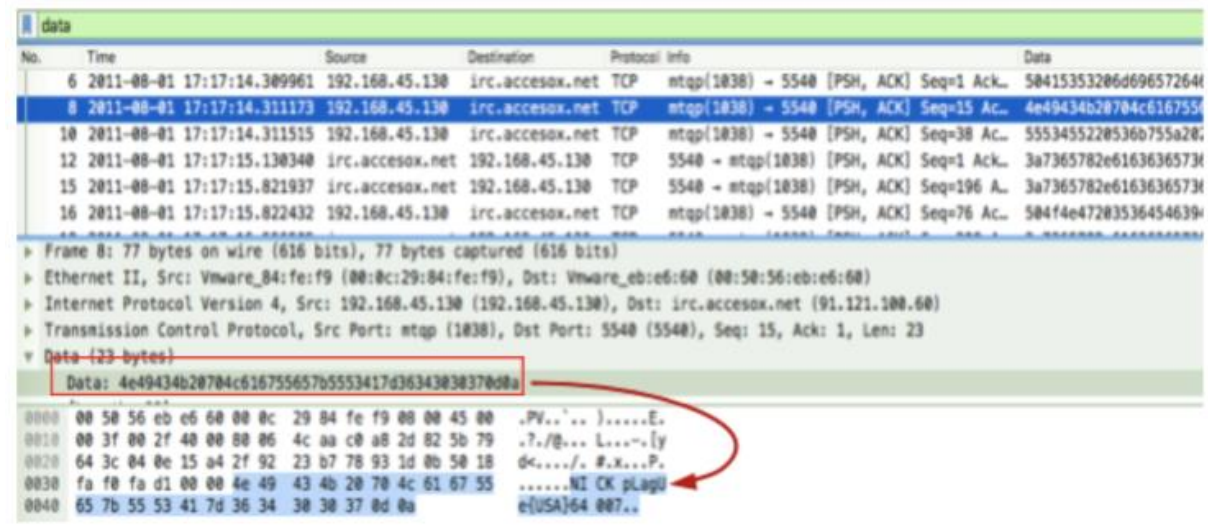

Gambar 5. Statistik Hirarki Protokol

Seperti ditunjukkan pada gambar 4, bahwa selain hirarki protokol juga ditunjukkan pembacaan data dari protokol yang ditampilkan. Pembacaan dari data protokol seperti ditunjukkan pada gambar 4 memastikan hasil pembacaan excerpt dari aliran TCP (gambar 3.), dimana berisi informasi keberadaan dan aktivitas botnet.

\section{PENUTUP \\ Simpulan}

Pada jaringan IRC publik dimana banyak terdapat serangan-serangan oleh malware maupun virus, perlu diketahui mekanisme pemicu serangan-serangan tersebut. Salah satu pemicu serangan-serangan tersebut adalah botnet. Berdasarkan pengamatan dan analisis terhadap jaringan IRC dengan alat bantu Wireshark maka dapat ditampilkan excerpt dari aliran TCP, serta data dari semua protokol tertangkap, yang tersusun secara hirarkis. Berdasar pemahaman terhadap pembacaan Wireshark dengan disesuaikan terhadap RFC 2812, dapat diketahui informasi mengenai aktivitas botnet pada lalu lintas jaringan IRC. Dengan diketahuinya aktivitas botnet pada jaringan IRC, maka selanjutnya dapat digunakan sebagai acuan pembuatan aturanaturan pada pengelolaan jaringan, seperti misalnya aturan-aturan pada firewall, aturan-aturan pada mekanisme routing, aturan-aturan pada pengelolaan server, dan sebagainya.

\section{DAFTAR PUSTAKA}

Alothman, Basil \& Rattadilok, Prapa. (2017). Towards using Transfer Learning for Botnet Detectoin. 12 ${ }^{\text {th }}$ International Conference for Internet Technology and Secured Transaction (ICITST-2017). University of Cambridge, Cambridge

Puri, Ramneek. (2003). Bots \&; Botnet: An Overview. SANS Institute, Singapore 
Kasperzyk, Rafal., Paz, Marcin., dan Tarapata, Zbigniew. (2017). Modelling and simulation of botnet based cyber-threats. MATEC Web Conferences Volume 125, 21st International Conference on Circuits, Systems, Communications and Computers (CSCC 2017). Crete: eo sciences

Kamluk, Vitaly. (2008, 18 Juli). Biznes botnetnowy. [online] Tersedia di https://tech.money.pl/hi-tech/artykul/biznes-botnetowy,212,0,356308.html [Diakses 27 Juni 2019]

Sfakianakis, Andreas., Douligeris, Christos., Marinos, Louis., Lourenço, Marco., \& Raghimi, Omid. (2019). ENISA Threat Landscape Report 2018: 15 Top Cyberthreats and Trends. DOI: $10.2824 / 622757$

Godkin T., (2013), Statistical Assessment of Peer-to-Peer Botnet Features, University of Victoria Bloice, Graham., 2019. Tshark Command Line using PowerShell, [online] Tersedia di: <https://sharkfesteurope.wireshark.org/assets/presentations17eu/33.7zl> [Diakses 18 Februari 2019]

Kalt, C. 2000. RFC 2812-Internet Relay Chat: Client Protocol - IETF Tools, [online] Tersedia di: https://tool.ietf.org/html/rfc2812 [Diakses 21 Januari 2019] 